\title{
DESOXYRIBONUCLEASE I ACTIVITY IN PANCREATIC DISEASE ${ }^{1}$
}

\author{
By O. D. KOWLESSAR 2 AND R. K. MCEVOY \\ (From the Division of Experimental Radiology and Surgery, University of Rochester School \\ of Medicine and Dentistry, Rochester, New York)
}

(Submitted for publication October 21, 1955; accepted June 11, 1956)

The depolymerases (DNase I and II) of desoxyribonucleic acid (DNA) are among the enzymes present in the blood of man and animals (1-3). Since the activity of DNase I in pancreatic tissue is considerably higher than that in other tissues of the body (4), it was postulated by the senior author that an inflammatory or destructive process within the pancreas might result in an alteration of the DNase activity normally observed in the blood. The present investigation was undertaken in order to explore the possibility of using the level of serum DNase I as an index of pancreatic damage. A study of DNase I activity was made on the blood of normal human subjects, of patients with pancreatic and other diseases and of animals with experimentally-induced pancreatitis.

\section{METHODS}

The patients included 32 normal subjects, 25 hospitalized patients with various diseases unrelated to the pancreas, and 34 patients suspected of having pancreatic disease and in whom the serum amylase level was 200 units or more. The latter group of patients was subdivided into the groups shown in Tables III and IV on the basis of the laboratory data and the clinical course of their disease including autopsy or operative findings. Single samples of venous blood were drawn from the first and second groups, whereas blood samples were taken every other day from patients with high serum amylase levels.

Edematous pancreatitis was produced in dogs by the following technique. Of five mongrel dogs of both sexes weighing 9.5 to $11 \mathrm{Kg}$., the pancreatic ducts of three were ligated according to the technique described by Radakovich, Pearse, and Strain (5) and the pathological changes in the pancreas were confirmed by postmortem examination. In the two control dogs, the pancreatic glands were exposed and manipulated but not removed. All the animals were permitted to eat and drink ad libitum postoperatively. Blood was withdrawn daily from the femoral vein for three days preoperatively

\footnotetext{
1 Supported in part by a grant from the United States Atomic Energy Commission.

2 Present address: The New York Hospital, 525 East 68th Street, New York 21, N. Y.
}

and nine days postoperatively. The serum was separated immediately and assayed for DNase I and amylase.

The following procedure was employed to induce acute pancreatitis in rats. Forty-eight Sprague-Dawley rats of both sexes, weighing 180 to $200 \mathrm{gm}$., were divided randomly into two groups, one of which was given intraperitoneal injections of one $\mathrm{mg}$. DL-ethionine ${ }^{8}$ in aqueous solution at $50^{\circ} \mathrm{C}$ daily for five days. The control animals were injected intraperitoneally with an equal volume of warm isotonic saline. Both groups were fasted for twelve hours prior to the start of the experiment. The animals were allowed to eat ground Purina fox chow ad libitum after the initial period of fasting preceding the first injection. The daily food intake of each animal was weighed and the average amount of food eaten by individual rats in the experimental group was given to each control animal on the following day. Four rats of each group were sacrificed by decapitation on the first, second, third, fourth and fifth days after the first injection. Blood was collected in tubes containing $2 \mathrm{mg}$. of heparin. The plasma was diluted 1:4 with distilled water and assayed for DNase I and amylase. All the animals were autopsied and the gross findings noted.

DNase I activity was determined by a modification of the method of Allfrey and Mirsky (4). A highly polymerized preparation of sodium desoxyribonucleate obtained from calf thymus according to the method of Kay, Simmons, and Dounce (6) was used as substrate, and tris (hydroxymethyl) aminomethane served as buffer. Enzymatic activity is expressed in micrograms of desoxypentose phosphorus liberated from the substrate per hour of incubation. Serum amylase was determined according to the method of Somogyi (7).

\section{Clinical}

\section{RESULTS}

The mean and standard error of DNase I activity in the serum of normal individuals and in patients with pancreatic disease and other illnesses are summarized in Table I. The serum DNase values of normal individuals range from .076 to $1.25 \mu \mathrm{g}$. of desoxypentose-P per ml. per hour of incubation, with a mean of $.46 \pm .06 \mu \mathrm{g}$. The DNase I activity in the group of randomly selected patients seen in Tables I and II does not deviate

3 Nutritional Biochemicals Corp., Inc. 
TABLE I

DNase I activity * in human sera

\begin{tabular}{lcc}
\hline \hline \multicolumn{1}{c}{ Serum } & $\begin{array}{c}\text { Number of } \\
\text { patients } \\
\text { studied }\end{array}$ & $\begin{array}{c}\text { Mean } \\
\text { activity } \\
\text { and standard } \\
\text { deviation } \\
\text { of mean }\end{array}$ \\
\hline $\begin{array}{l}\text { Healthy controls } \\
\text { Controls with various } \\
\text { diseases other than }\end{array}$ & 32 & $.46 \pm .06$ \\
$\begin{array}{l}\text { pancreatitis } \\
\text { Pancreatic diseasest }\end{array}$ & 25 & $.48 \pm .05$ \\
$\begin{array}{l}\text { A. Edematous pancreatitis } \\
\text { B. Mumps pancreatitis }\end{array}$ & 13 & $.63 \pm .05$ \\
$\begin{array}{l}\text { C. Pancreatic cysts } \\
\text { D. Pancreatic fistula }\end{array}$ & 2 & $.65 \pm .1$ \\
$\begin{array}{l}\text { E. Carcinoma of pancreas } \\
\text { F. Acute hemorrhagic } \\
\text { pancreatitis }\end{array}$ & 1 & $.49 \pm .12$ \\
& 10 & $.49 \pm .44$ \\
\hline
\end{tabular}

* DNase I activity $=\mu \mathrm{g}$. of desoxypentose-P $/ \mathrm{hr} . / \mathrm{ml}$. $\dagger$ Enzyme activity expressed as the mean of the average value for each patient within a group.

significantly from the normal level. Table III shows the individual determinations of serum amylase and of DNase $I$ in a series of 23 patients, all of whom were chosen because of elevation of the serum amylase and suspected pancreatic disease. It will be noted that the serum DNase levels

TABLE II

DNase $I$ activities in sera of patients with various disorders

\begin{tabular}{|c|c|c|c|}
\hline No. & Patient & Diagnosis & $\begin{array}{l}\text { DNase I } \\
\text { activity }\end{array}$ \\
\hline $\begin{array}{r}1 \\
2 \\
3 \\
4 \\
5 \\
6 \\
7 \\
8 \\
9 \\
10 \\
11 \\
12 \\
13 \\
14 \\
15 \\
16 \\
17 \\
18 \\
19 \\
20 \\
21 \\
22 \\
23 \\
24 \\
25\end{array}$ & $\begin{array}{l}\text { M. J. } \\
\text { J. W. } \\
\text { R.S. } \\
\text { A.T. } \\
\text { R. H. } \\
\text { L. B. } \\
\text { M.E. } \\
\text { R. M. } \\
\text { O. R. } \\
\text { B. D. } \\
\text { F. H. } \\
\text { D.S. } \\
\text { A. R. } \\
\text { A. G. } \\
\text { J. MCG. } \\
\text { E. V. } \\
\text { T. C. } \\
\text { E. C. } \\
\text { M. C. } \\
\text { W.S. } \\
\text { L. M. } \\
\text { N.F. } \\
\text { C. G. } \\
\text { C. C. } \\
\text { F. D. }\end{array}$ & $\begin{array}{l}\text { Hernia } \\
\text { Hypertension } \\
\text { Carcinoma of the breast } \\
\text { Pneumonia } \\
\text { Hyperthyroidism } \\
\text { Infectious hepatitis } \\
\text { Acute rheumatic fever } \\
\text { Rheumatoid arthritis } \\
\text { Tuberculosis of the lung } \\
\text { Cerebral vascular accident } \\
\text { Infectious hepatitis } \\
\text { Nephrotic syndrome } \\
\text { Pernicious anemia } \\
\text { Sarcoidosis } \\
\text { Myocardial infarction } \\
\text { Hodgkin's disease } \\
\text { Cirrhosis of the liver } \\
\text { Bronchopneumonia } \\
\text { Lupus erythematosus } \\
\text { Pneumonia } \\
\text { Leukemia } \\
\text { Pneumonia } \\
\text { Cirrhosis of the liver } \\
\text { Chronic glomerulonephritis } \\
\text { Thrombophlebitis }\end{array}$ & $\begin{array}{l}0.35 \\
0.62 \\
0.45 \\
0.38 \\
0.16 \\
0.23 \\
0.19 \\
0.30 \\
0.25 \\
0.45 \\
0.32 \\
0.40 \\
0.65 \\
0.85 \\
0.92 \\
1.10 \\
0.85 \\
0.32 \\
0.65 \\
0.15 \\
0.82 \\
0.35 \\
0.29 \\
0.65 \\
0.18\end{array}$ \\
\hline
\end{tabular}

* DNase I activity = $\mu \mathrm{g}$. of desoxypentose-P/hr./ml. of patients with interstitial pancreatitis are significantly higher than those of the controls at the 5 per cent level. Since repeated observation of these patients revealed a fall in DNase I, it appears likely that the initial serum DNase activity was slightly elevated. In contrast to the aforementioned cases, all ten patients with acute hemorrhagic pancreatitis proved at autopsy or exploration showed marked elevation of DNase I activity (Table IV). There was more than a five-fold increase beyond the highest value found in normal subjects.

\section{Experimental}

The serum DNase I and amylase levels of the operated and control dogs are shown in Figure 1. The DNase values in normal dogs ranged from 4.0 to $5.8 \mu \mathrm{g}$. desoxypentose-P per $\mathrm{ml}$. per hour of incubation with a mean of 4.83 . The marked temporary increase in serum amylase which occurred on the first and second postoperative day has been described by other authors $(8,9)$. The DNase I activity of the serum rose gradually to about two and one-half times the preoperative level and returned to normal by the seventh postoperative day.

The DNase I and amylase activities of the plasma of rats given ethionine and of their pairfed controls are shown in Figure 2. The values in normal rats ranged from 3.2 to $7.7 \mu \mathrm{g}$. desoxypentose-P per ml. per hour with a mean of 5.0. A marked increase occurred in the plasma DNase I activity of the ethionine-treated rats, whereas a decrease was noted in the plasma amylase during the first three days of the treatment. The amylase level rose on the fourth and fifth days, a finding reported previously by Henning and Heinkel (10). It should be pointed out that the food intake was reduced markedly on the fourth and fifth days of the ethionine administration. The animals became quite sick as a result of the treatment, and by the fifth day the surviving animals were moribund. The pathological changes in the pancreas and liver corresponded to those described previously (10). The pancreas of the control animals showed no necrosis or loss of basophilia of the acinar cells. There was a slight fatty change in the livers of the pair-fed controls, but no fibrosis or other signs of liver damage. 
TABLE III

Serum DNase $I^{*}$ and amylase levels ${ }^{\text {in }}$ sera from patients with various pancreatic disorders

\begin{tabular}{|c|c|c|c|c|c|c|c|c|}
\hline \multirow[b]{2}{*}{ Patlent } & & \multicolumn{7}{|c|}{ Day of illness } \\
\hline & & 1 & 2 & 3 & 4 & 5 & 6 & 7 \\
\hline \multicolumn{9}{|c|}{ Acute interstitial pancreatitis } \\
\hline $\begin{array}{l}\text { M. S. } \\
\text { L. L. } \\
\text { A. D. } \\
\text { A. T. } \\
\text { S. D. } \\
\text { B. S. } \\
\text { S. T. } \\
\text { L. R. } \\
\text { M. C. } \\
\text { J. B. } \\
\text { N. T. } \\
\text { F. L. } \\
\text { C. G. }\end{array}$ & $\begin{array}{l}\text { (Amylase) } \\
\text { (DNase) } \\
\text { (Amylase) } \\
\text { (DNase) } \\
\text { (Amylase) } \\
\text { (DNase) } \\
\text { (Amylase) } \\
\text { (DNase) } \\
\text { (Amylase) } \\
\text { (DNase) } \\
\text { (Amylase) } \\
\text { (DNase) } \\
\text { (Amylase) } \\
\text { (DNase) } \\
\text { (Amylase) } \\
\text { (DNase) } \\
\text { (Amylase) } \\
\text { (DNase) } \\
\text { (Amylase) } \\
\text { (DNase) } \\
\text { (Amylase) } \\
\text { (DNase) } \\
\text { (Amylase) } \\
\text { (DNase) } \\
\text { (Amylase) } \\
\text { (DNase) }\end{array}$ & $\begin{array}{c}30 \\
1.7 \\
20 \\
0.9 \\
23.6 \\
0.9 \\
16 \\
0.7 \\
20 \\
0.8 \\
16 \\
0.7 \\
17 \\
1.0 \\
6.8 \\
0.5 \\
12 \\
0.7 \\
20 \\
0.9 \\
15 \\
0.8 \\
12 \\
1.1 \\
8 \\
0.9\end{array}$ & $\begin{array}{c}26 \\
1.5 \\
18 \\
0.9 \\
12 \\
0.5 \\
12 \\
0.4 \\
17 \\
0.7 \\
8 \\
0.5 \\
8.5 \\
0.8 \\
6 \\
0.5 \\
8 \\
0.7 \\
18 \\
0.9 \\
11 \\
0.7 \\
6 \\
0.9 \\
6 \\
0.8\end{array}$ & $\begin{array}{l}13 \\
0.9 \\
\\
8 \\
0.3 \\
5.2 \\
0.3 \\
5.5 \\
0.6 \\
2 \\
0.3 \\
5.2 \\
0.7 \\
4.2 \\
0.5\end{array}$ & $\begin{array}{l}4 \\
0.6 \\
7 \\
0.6 \\
5 \\
0.6 \\
1 \\
0.6 \\
2 \\
0.5\end{array}$ & $\begin{array}{l}6 \\
0.6 \\
\\
\\
1.2 \\
0.2 \\
0.8 \\
0.2 \\
2.2 \\
0.4 \\
0.8 \\
0.3 \\
3 \\
0.7 \\
3 \\
0.3 \\
\\
4 \\
0.5\end{array}$ & $\begin{array}{l}1 \\
0.2 \\
1.2 \\
0.5 \\
1.0 \\
0.3 \\
2 \\
0.5\end{array}$ & $\begin{array}{l}2 \\
0.5 \\
1.5 \\
0.4\end{array}$ \\
\hline \multicolumn{9}{|c|}{ Mumps pancreatitis } \\
\hline $\begin{array}{l}\text { R. P. } \\
\text { L. M. }\end{array}$ & $\begin{array}{l}\text { (Amylase) } \\
\text { (DNase) } \\
\text { (Amylase) } \\
\text { (DNase) }\end{array}$ & $\begin{array}{l}4.2 \\
0.4 \\
2.8 \\
0.4\end{array}$ & & $\begin{array}{l}2.5 \\
0.4 \\
1.8 \\
0.3\end{array}$ & & $\begin{array}{l}1.2 \\
0.3 \\
0.8 \\
0.2\end{array}$ & & $\begin{array}{l}0.8 \\
0.3\end{array}$ \\
\hline \multicolumn{9}{|c|}{ Pancreatic cyst } \\
\hline $\begin{array}{l}\text { N. T. } \\
\text { B. N. } \\
\text { J.S. } \\
\text { H. B. }\end{array}$ & $\begin{array}{l}\text { (Amylase) } \\
\text { (DNase) } \\
\text { (Amylase) } \\
\text { (DNase) } \\
\text { (Amylase) } \\
\text { (DNase) } \\
\text { (Amylase) } \\
\text { (DNase) }\end{array}$ & $\begin{array}{r}12.5 \\
0.8 \\
16.5 \\
0.5 \\
22 \\
0.9 \\
17 \\
1.1\end{array}$ & $\begin{array}{c}9 \\
0.6 \\
12.5 \\
0.4 \\
15 \\
0.9 \\
16 \\
1.0\end{array}$ & $\begin{array}{c}10 \\
0.6 \\
11 \\
0.4 \\
12 \\
0.8 \\
9 \\
1.0\end{array}$ & $\begin{array}{l}6 \\
0.7\end{array}$ & $\begin{array}{l}4.5 \\
0.6 \\
6.5 \\
0.3 \\
5.0 \\
0.7 \\
2 \\
0.6\end{array}$ & $\begin{array}{l}0.8 \\
0.6\end{array}$ & $\begin{array}{l}2 \\
0.5 \\
1.2 \\
0.3 \\
1.0 \\
0.5\end{array}$ \\
\hline \multicolumn{9}{|c|}{ Carcinoma of pancreas } \\
\hline $\begin{array}{l}\text { E. L. } \\
\text { L. B. } \\
\text { V.A. } \\
\text { H.S. }\end{array}$ & $\begin{array}{l}\text { (Amylase) } \\
\text { (DNase) } \\
\text { (Amylase) } \\
\text { (DNase) } \\
\text { (Amylase) } \\
\text { (DNase) } \\
\text { (Amylase) } \\
\text { (DNase) }\end{array}$ & $\begin{array}{l}5.5 \\
0.3 \\
4.5 \\
0.5 \\
6.5 \\
0.5 \\
8.5 \\
0.8\end{array}$ & $\begin{array}{l}4.6 \\
0.3 \\
6.2 \\
0.4 \\
6.2 \\
0.5 \\
6.5 \\
0.7\end{array}$ & & $\begin{array}{l}5.9 \\
0.4 \\
5.2 \\
0.4 \\
6.2 \\
0.7\end{array}$ & $\begin{array}{l}4.8 \\
0.3 \\
3.5 \\
0.3\end{array}$ & $\begin{array}{l}7.6 \\
0.2 \\
\\
4.2 \\
0.3 \\
6.0 \\
0.6\end{array}$ & $\begin{array}{l}3.5 \\
0.3\end{array}$ \\
\hline
\end{tabular}

* DNase $=\mu \mathrm{g}$. of desoxypentose-P/hr. $/ \mathrm{ml}$.

+ Amylase units $\times 10^{\circ}$.

\section{DISCUSSION}

The results reported in this paper suggest that a marked and protracted elevation of serum DNase I occurs clinically in pancreatic disease only when tissue breakdown is one of the pathologic features -i.e., as in acute hemorrhagic pancreatitis. These findings can be correlated with those noted in ethionine-induced pancreatitis in the rat and with 
TABLE IV

DNase $I^{*}$ and amylase levels $\dagger$ in sera from patients with acute hemorrhagic pancreatitis

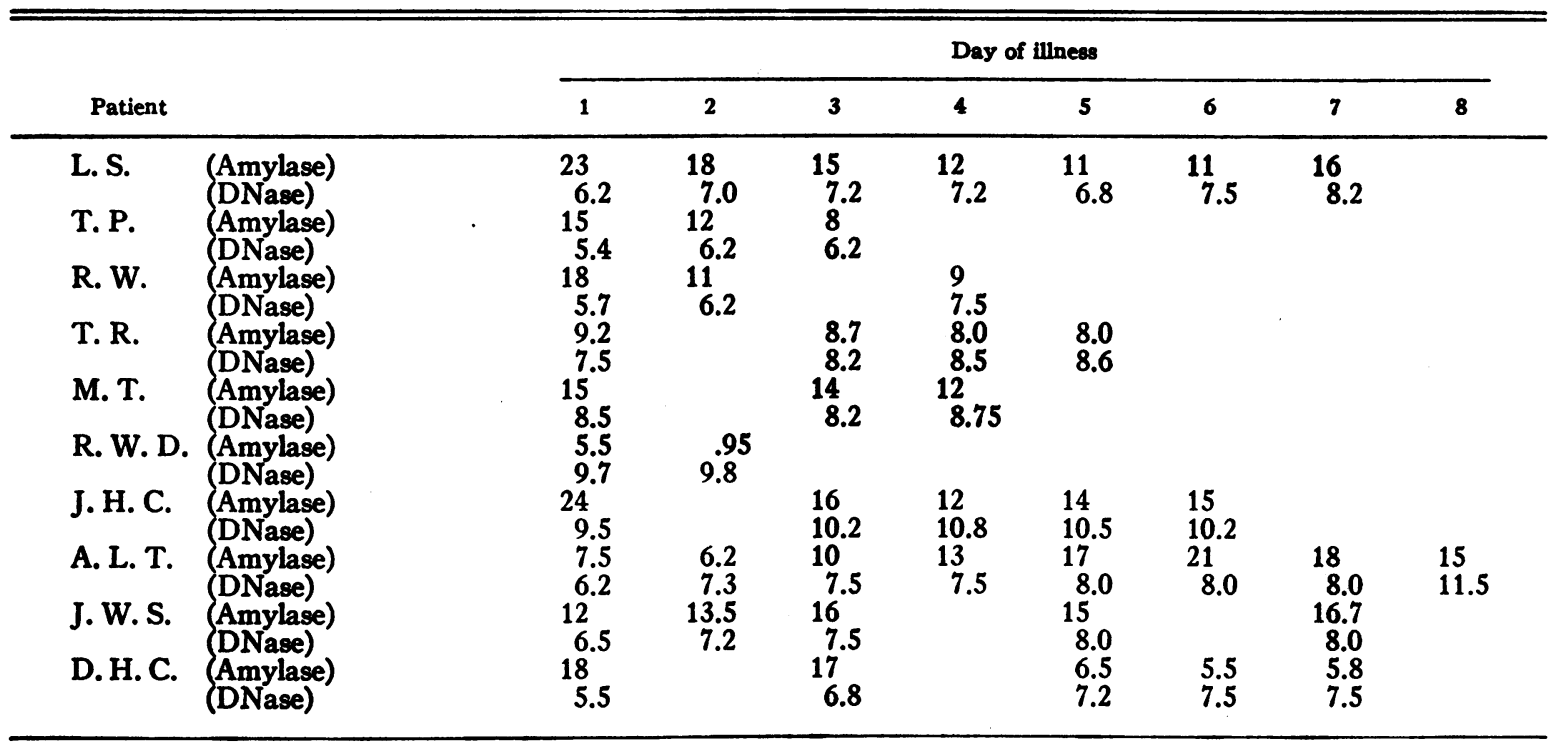

* DNase $=\mu \mathrm{g}$. of desoxypentose-P/hr. $/ \mathrm{ml}$.

$\uparrow$ Amylase units $\times 10^{2}$.
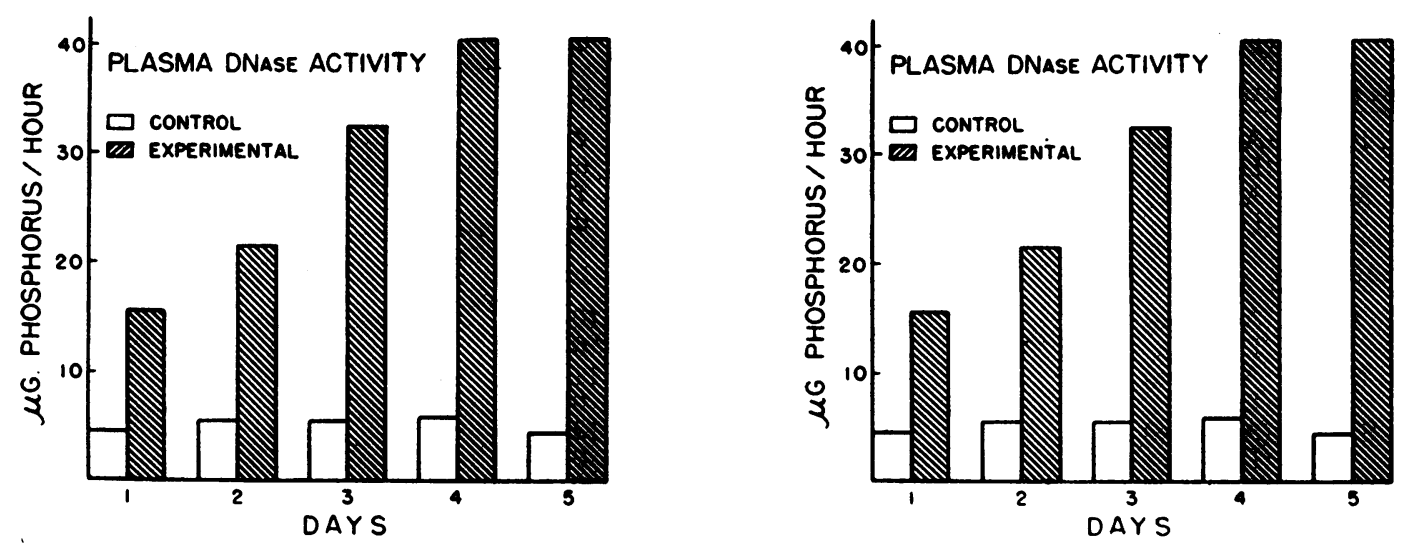

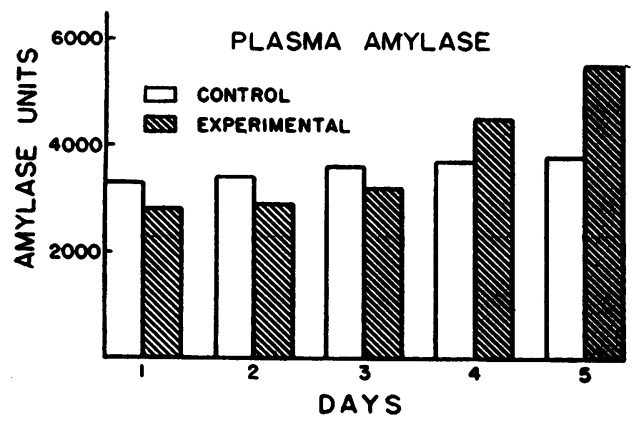

Fig. 1. Average Serum DNase I and Amylase Levers in Dogs with Ligated Pancreatic Ducts and in Sham-Oprarated Controls

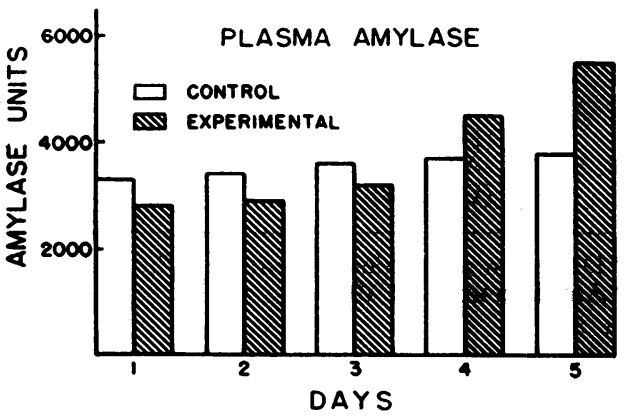

Fig. 2. Average Plasma DNase I and Amylase Activity in Rats Treated with Ethionine aNd IN Pan-Fed Untreatro Controls 
the gradual increase in plasma DNase I activity occurring subsequent to tissue destruction in irradiated rats $(11,12)$. When pancreatic dysfunction in patients was the result of an inflammatory process not accompanied by necrosis, or when it resulted from operative ligation of the pancreatic ducts in dogs, the DNase activity of the blood increased to approximately twice the preoperative level.

Since this and other studies of serum DNase I activity in patients with a variety of diseases unrelated to the pancreas show normal enzyme activity, it seems likely that the pancreas plays a key role in the production and distribution of DNase $\mathrm{I}$. The high concentration of this enzyme in the pancreatic juice of a dog with a pancreatic fistula (4) supports such a theory, as does the observation in this laboratory of a reduced DNase activity in the duodenal juice of patients with pancreatic fibrosis. Whether DNase I has an exocrine digestive function remains to be established, but its $\mathrm{pH}$ optimum (7.6) is compatible with such an action.

Once these findings have been firmly established by more extensive clinical studies, the diagnostic applications are evident. The serum amylase test for pancreatic disease, the laboratory test most extensively used, is subject to limitations $(13,14)$ and is not specific for pancreatic disease, being abnormal in many other conditions (15-20). Since DNase $I$ is found in high concentrations only in the pancreas and pancreatic juice, alteration in its activity in serum may provide information which will supplement that gained from amylase assay and other studies. In particular, the level of DNase I activity may be of specific value in the diagnosis of necrosis of pancreatic tissue such as is found in acute hemorrhagic necrosis.

\section{SUMMARY AND CONCLUSIONS}

1. Serum DNase I was determined in 32 normal human subjects, 25 patients with various diseases unrelated to the pancreas, and 34 patients with pancreatic disease. A marked and protracted elevation in enzyme activity occurred only in patients with acute hemorrhagic pancreatitis. A temporary elevation to the upper limit of normal was noted in patients with edematous pancreatitis.

2. Serum DNase I activity was observed to be temporarily elevated in three dogs after ligation of the pancreatic ducts.

3. Plasma DNase I showed a marked and sustained elevation in rats with ethionine-induced pancreatitis.

4. It was concluded that a marked and sustained rise in blood DNase I activity was noted when there was true necrosis of pancreatic tissue.

\section{REFERENCES}

1. Kurnick, N. B., Desoxyribonuclease activity of sera of man and some other species. Arch. Biochem. \& Biophys., 1953, 43, 97.

2. McCarty, M., The inhibition of streptococcal desoxyribonuclease by rabbit and human antisera. $J$. Exper. Med., 1949, 90, 543.

3. Wróblewski, F., and Bodansky, O., Presence of desoxyribonuclease activity in human serum. Proc. Soc. Exper. Biol. \& Med., 1950, 74, 443.

4. Allfrey, V., and Mirsky, A. E., Some aspects of the desoxyribonuclease activities of animal tissues. J. Gen. Physiol., 1952, 36, 227.

5. Radakovich, M., Pearse, H. E., and Strain, W. H., Study of the etiology of acute pancreatitis. Surg., Gynec. \& Obst., 1952, 94, 749.

6. Kay, E. R. M., Simmons, N. S., and Dounce, A. L. An improved preparation of sodium desoxyribonucleate. J. Am. Chem. Soc., 1952, 74, 1724.

7. Somogyi, M., Blood diastase as an indicator of liver function. Proc. Soc. Exper. Biol. \& Med., 1934, $32,538$.

8. Lium, R., and Maddock, S., Etiology of acute pancreatitis. An experimental study. Surgery, 1948, 24, 593.

9. Thistlethwaite, J. R., and Hill, R. P., Serum amylase levels in experimental pancreatitis. Surgery, 1952, 31, 495.

10. Henning, N., and Heinkel, K., Untersuchungen über die Äthioninpankreatitis der Ratte. Ztschr. f. d. ges. exper. Med., 1953, 120, 221.

11. Kowlessar, O. D., Altman, K. I., and Hempelmann, L. H., The effect of ionizing radiation on deoxyribonuclease activities of body fluids. I. The effect of total body exposure on the urinary excretion of deoxyribonucleases. Arch. Biochem. \& Biophys., 1954, 52, 362.

12. Kowlessar, O. D., Altman, K. I., and Hempelmann, L. H., The effect of ionizing radiation in desoxyribonuclease activities of body fluids. II. The plasma DNases after total body irradiation. Arch. Biochem. \& Biophys., 1955, 54, 355.

13. McCorkle, H., and Goldman, L., The clinical significance of the serum amylase test in the diagnosis of acute pancreatitis. Surg., Gynec. \& Obst., 1942, 74, 439.

14. Cole, W. H., Acute pancreatitis, with special reference 
to pathogenesis and the diagnostic value of the blood amylase test. Am. J. Surg., 1938, 40, 245.

15. Hinton, J. W., The evaluation of end results in physiological versus pathologic operative procedures for chronic duodenal ulcer during the past two decades. Ann. Surg., 1950, 132, 641.

16. Probstein, J. G., Wheeler, P. A., and Gray, S. H., Perforated peptic ulcer, its differentiation from acute pancreatitis by blood diastase determination. J. Lab. \& Clin. Med., 1939, 24, 499.

17. Henstell, H. H., and Freedman, R. I., An inhibitor of desoxyribonuclease in human white blood cells and bone marrow cells and its relationship to cellular maturity. Science, 1952, 115, 357.
18. Henstell, H. H., Freedman, R. I., and Ginsburg, B., An inhibitor of desoxyribonuclease in human white blood and bone marrow cells, and its relationship to cellular maturity. Cancer Research, 1952, 12, 346.

19. Howell, C. W., and Bergh, G. S., Pancreatic duct filling during cholangiography: its effect upon serum amylase levels. Gastroenterology, 1950, 16, 309.

20. Gross, H. B., Comfort, M. W., Mathieson, D. R., and Power, M. H., Elevated values for serum amylase and lipase following the administration of opiates: a preliminary report. Proc. Staff Meet., Mayo Clin., 1951, 26, 81.

\section{SPECIAL NOTICE TO SUBSCRIBERS}

Post Offices will no longer forward the Journal when you move.

Please notify The Journal of Clinical Investigation, Business Office, 622 West 168th Street, New York 32, N. Y. at once when you have a change of address, and do not omit the zone number if there is one. 